\title{
THE NEW ILLINOIS CIVIL PRACTICE ACT
}

\author{
Charles E. Clark*
}

$\mathrm{P}$ ASSAGE of a new practice act controlling the civil procedure in the courts of the State of Illinois is an event of major importance not only in the jurisprudence of the state but also in the procedural history of the nation. The wave of reform of court procedure, which originated in New York in the middle of the last century and spread to a majority of the states, seemed to have dispelled itself some years ago so far as major changes in an entire state code were concerned. Recent procedural developments have been himited in the main to the perfection of special devices such as the summary judgment, the declaratory judgment and discovery before trial. ${ }^{x}$ The adoption of a new practice in one of our great states is therefore notable particularly when that state is the one long regarded as the outstanding stronghold of the ancient forms-the example to which law professors might still point of the enduring importance of common law pleading. ${ }^{2}$

The invitation of the editors of the University of Chicago Law Review to comment upon this new Act has caused me not a little trepidation. One not immediately familiar with local practice cannot warn bench and bar of pitfalls so well as can local authors. The clear statement already published in this review and the announcement of at least one new and authoritative book on the Act by authors not only highly competent, but at least

* Dean, Yale University School of Law.

* The adoption of a new civil practice act in New York in I920, effective in I92I, which was most disappointing in its limitations, does not call for modification of the text. For citations concerning the history and effect of this act see my book on Code Pleading (rg28), 25-27. Changes in Michigan, Pennsylvania, and New Jersey have been more extensive, ibid. 2I, 22; E. R. Sunderland, The New Michigan Court Rules, 29 Mich. L. Rev. 586 (I93I).

2 "It is an old story how Lord Chief Justice Russell felicitated the lawyers of Illinois forty years ago, when he was guest at a Chicago reception, on the fact that their state had provided the only park in the world for the preservation of ancient species of pleading and procedure." Illinois Procedure Goes Modern, I7 Am. Jud. Soc. J. 40 (I933). This is not, however, a characterization entirely fair and there is much in the statement of ex-Chief Justice Floyd E. Thompson to the Illinois lawyers that they had been practicing "code practice" ever since they practiced law. Rep. Ill. St. Bar Ass'n, 1932, 269. In fact the former provision, Ill. Rev. St. I93I, C. IIO, $\$ 40$, for transfer of a case from law to chancery or vice versa, where a party has misconceived his remedy, may turn out to have been as broad as the new provision in C. P.A. Sec. 44 (2), discussed below. 
partly responsible for its drafting, will supply this need of the profession. ${ }^{3}$ I concluded, therefore, that I should attempt rather some appraisal of the Act against the general background of procedural reform in this country and England. I reahze even here the danger of criticism which may not be justified in view of local conditions of which I am not informed. What may have been a wholly justifiable compromise in view of political or other difficulties may strike an outsider, not familiar with the campaign strategy, as unfortunate. The published history of the legislative movement is unfortunately all too brief. We are told that at least four different drafts were prepared. ${ }^{4}$ Two of the earlier ones have been available ${ }^{5}$ as well as the report of the discussion before the state bar association. ${ }^{6}$ All of this, however, leaves much to be desired in any attempt to learn the complete story. One wonders, for example, why the quite satisfactory and simple provisions for the declaratory judgment, now so thoroughly established as a desirable procedural device, were omitted from the statute apparently at the last moment. ${ }^{7}$ But after all it may be worth while to consider the Act apart from the necessities of the moment attending its passage and in the light of its long-time value.

It should be said at once that the Act contains many and most valuable procedural improvements. Thus the liberal provisions for joinder of actions, including joinder of parties and of causes of actions and the pleading of counterclaims, which provide for practically unlimited joinder within the bounds of trial convemence, are as enlightened as any in the country and compare favorably with the Enghish rules. The sections providing for waiver of jury trial by failure to make claim therefor, for summary judg-

3 A. E. Jenner, Jr., and Walter V. Schaefer, The Proposed Illinois Civil Practice Act, I Univ. Chi. L. Rev. 49-7I (I933); Illinois Civil Practice Act Annotated, O. L. McCaskill, editor, and Messrs. Jenner and Schaefer, associate editors, annonnced for December I, I933.

4 See Jenner and Schaefer, op. cit., supra, note 3.

5 The draft, Proposed Consolidated Civil Practice Act, submitted by the Committee on Judicial Administration of the Illinois State Bar Association for the consideration of the bench and bar, hereinafter called Original Draft; and the bill presented to the Legislature in r933, Senate Bill No. 359, hereinafter called the Bill.

${ }^{6}$ Rep. Illinois St. Bar Ass'n, 1932, 316-326.

7 The provisions appear as Section 30 of the Original Draft and Section 58 of the Bill and are discussed by Jenner and Schaefer, op. cil., supra, note 3. Meanwhile the United States Suprene Court, by consenting to review a Tennessee declaratory judgnient and affirming its validity, had removed the last obstacle (occasioned by earlier expressions of the same court) to the coinplete acceptance of the remedy. Nashville, Cliattanooga \& St. Louis Railway v. Wallace, 288 U.S. 249, 53 Sup. Ct. 345 (I933); I Univ. Chi. L. Rev. I32 (I933); 46 Harv. L. Rev. 850 (I933); 3I Micl. L. Rev. 7 IO (I933); 42 Yale L. Jour. 974 (I933). 
ments, ${ }^{8}$ and for examination of parties and discovery of documents before trial are admirable, as are the more liberal rules regarding service of process and the speeding up of the time for returning process and securing review and the system of control and of restriction of the granting of continuances. The various steps taken towards simphification of appellate practice-referred to hereinafter more at length—are, if not revolutionary, at least steps in the right direction. So is also the grant of certain, although unfortunately incomplete, rule-making authority to the Illinois Supreme Court. Making all due allowances, however, for substantial gains, one cannot avoid regret that an act in many ways so extensive in character and so upsetting to the present settled habits of bench and bar did not go still further to establisl an outstanding system of practice. Members of the profession will now find that they must adjust themselves to an essentially new procedure. There would have been no additional hardship in going the complete distance in the way of reform.

A major difficulty, it is feared, will be found in the gingerliness, not to say timidity, with which the draftsmen have approached the fundamental question of the abolition of forms of action and the union of law and equity. In their basic enactment they seem to say that only the nomenclature of the forms of actions is dispensed with, while separate procedures in law and equity are to be maintained. On the other hand, provisions later for free joinder of all sorts of claims and for the shifting of actions from one docket to another are at war with such a purpose. The conflict in point of view contains seeds of much trouble. One can hope that the Illinois judiciary will ignore the bhind provisions as to the abohition of forms and will achieve a simphified procedure through whole-hearted apphication of the joinder rules. Unfortunately experience elsewhere teaches us that the weight of past practice and precedents usually holds the courts back from giving early and complete effect to practice reforms. The announced rules ought to be the ideal, abreast if not ahead of the actual experience. In the present instance, however, a bold judiciary must be relied on to go further than do the legislators.

${ }^{8}$ The provisions for summary judgment (sections 57 , ro2), good as far as they go, are still overrestricted in the kinds of actions to which they apply, in the lack of definite authority to the court to decide questions of law on the summary proceedings, and in the lack of authority to grant such judgments to defendants. See Finch, Summary Judgment Procedure, $x_{9} \mathrm{Am}$. Bar Ass'n. Jour. 504 (1933); Clark and Samenow, The Summary Judgment, 38 Yale L. Jour. 423 (r929). The motion to dismiss by the defendant on affidavit showing release, Statute of Frauds, etc. of C. P. A., $\S 48$, is taken from New York practice and is also desirable, though apparently defendants rarely seek summary action. 
In this connection the thoroughgoing statements of the original New York Code of 1848 , the model for the practice in a majority of states, should be compared with the new Illinois provisions. That Code, as drafted by David Dudley Field and his associates, provided:

The distinction between actions at law and suits in equity, and the forms of all such actions and suits heretofore existing, are abohished; and there shall be in the state, hereafter, but one form of action for the enforcement or protection of private rights and the redress or prevention of private wrongs, which shall be denominated a civil action. ${ }^{9}$

Whereas Section 3r of the Illinois Act states that:

Neither the names heretofore used to distinguish the different ordinary actions at law, nor any formal requisites heretofore appertaining to the manner of pleading in such sections respectively, shall hereafter be deemed necessary or appropriate, and there shall be no distinctions respectimg the manner of pleading between such actions at law and suits in equity, other than those specified in this Act and the rules adopted pursuant thereto; but this section shall not be deemed to effect in any way the substantial averments of fact necessary to state any cause of action either at law or in equity.

In the first statute the announced purpose is to blot out the distinctions between the actions and achieve one single form; in the second it is only to dispense with the necessity of names and formal requisites, but with the vitally important exception that separate actions at law and suits in equity exist and only the distinction in the manner of pleading is abohshed.

Moreover in Section 44 (2) of the Act there is a reference to "the law docket" and "the equity docket" and provision is made for transferring an action from one to the other, although in Rule $\mathrm{I}_{3}$ (Section 107) the clerk is directed to maintain apparently a single trial court docket upon which appear all the cases. Section I makes the Act applicable, with certain specified exceptions, to "all civil proceedings, both at law and in equity," while Section 9 (3) revivifies that grand old anachronism, "actions for injunctions to stay proceedings at law" which, appropriately, "shall be brought in the county in which the proceedings at law are had."Io

On the other hand, Section $3^{8}$ and Section 44 (I) of the Act provide for the filing of all counterclaims, including recoupments and cross-bills in equity; while the latter section also authorizes the joiming of "any causes of action, whether legal or equitable or both," and provides that legal and equitable issues may be tried together where no jury is eniployed. Section

9 N.Y. Laws, 1848, c. $379, \S 62$. For the present form of the statute see N.Y. Civil Practice Act, Art. $1, \S 8$, and Clark, Code Pleading (r928), 46, 47 .

so Under code practice, such injunctions (always suggesting an undignified contest between separate arms of the same sovereign) are unnecessary, except perhaps in contests with tribunals of other states or countries. 
43 provides for the filing of claims or defenses in the alternative and includes a reference to equitable defenses. ${ }^{\text {II }}$ It seems clear that in these sections it is expected that equitable and legal claims and defenses shall be considered in the same action and apparently in the same cause of action ${ }^{\mathrm{I2}}$ and, where a jury is waived, shall be tried together. When these provisions are coupled with that in Section 64 for automatic waiver of trial by jury upon failure to make seasonable claim therefor, a fairly complete amalgamation may be obtained if the separate law and equity dockets can be convemently forgotten or subordinated to the purpose of achieving unity.

Amalgamation of law and equity and abolition of forms of action is often objected to on the grounds that legal and equitable remedies are inherently different and that our law of rights grew out of our law of remedies. This is true but not particularly apt or pertinent to the problem how to get the issues in our modern cases most quickly and effectively before the court. The daily grist of a trial court is composed largely of contract and negligence cases wherein it hittle boots anyone to puzzle over the ancient distinctions among debt, covenant, account and assumpsit, general and special, or between trespass and case. In the more involved cases concerming our complex commercial hfe involving corporations and business trusts, debenture bonds and trust receipts, receiverships and reorgamizations, and new and unprecedented state and federal legislation, there is little occasion, at the issue-formulating stage of the case, to go back on historical excursions. Moreover where a judge is sitting without a jury, as lie does more and more when dockets become crowded and jury waiver automatic, it is not going to help him much in deciding whether or not to issue or continue an injunction to recall that once on a time there was an historic struggle between Coke and Ellsmere in which equity triumphed. It is true that occasionally at the trial such historical study may be apt and pertinent; but it slould be made only when it is of actual importance. So the difference in form of trial between equity and law, so much empliasized by our pleading pundits, may at times engage the court's attention and call for a real determination after a claim for jury trial is actually made. There is no occasion to consider this or others of these historical difficulties as forming iron limitations witlin which the pleadings must be lield for fear of the occasional case whicli at trial may

"Subsection 4 of $\$ 43$, in requiring the affirmative pleading of various defenses including fraud, makes no express distinction between equitable and legal defenses.

$x 2$ The advertisement for the new Illinois Civil Practice Act Annotated (see supra, note 3 ) states that there will be forms of a complaint in which legal and equitable claims are joined in the same suit without working a merger, and forms of complaints where a joinder does work a merger, affecting trial by jury. 
present the question. Too much fear has been expressed of dangers which in most cases will not arise at all and which can be met and disposed of without difficulty when they do arise. Thus the remote danger that a possible hitigant may at some time be deprived of his jury trial right by a failure of the court to perceive some of the historical connotations of his case is too unsubstantial a basis to justify ancient formalism in pleading in all cases.

One must admit that the treatment of the.union of law and equity in the state of its origin has not been designed to make the system seem attractive elsewhere. But it cannot be too strongly empliasized that it was not the system but the resistance to it which has led to the unfortunate situation in New York. In the classic phrase of Chief Justice Winslow of Wisconsin: "The cold, not to say inhuman, treatment which the infant code received from the New York judges is matter of history. They had been bred under the common-law rules of pleading and taught to regard that system as the perfection of logic, and they viewed with suspicion a system which was heralded as so simple that every man would be able to draw his own pleadings. They proceeded by construction to impart into the code rules and distinctions from the common-law system to such an extent that in a few years they had practically so changed it that it could hardly be recognized by its creators." ${ }^{2}$ Even within comparatively recent years the Appellate Division of the First Department in New York City has been dismissing cases because brought, as the court thought, by mistake, either "at law" or "in equity," when the dismissal meant only beginning the case over again in the same way in the same court. ${ }^{14}$ But for many years the Appellate Division courts of at least tlree of the four New York departments had arrived at a sensible and workable interpretation of the Code, and this now seems to be the case in the First Department also under the leadership of the present able presiding judge, whose understanding attitude towards procedural matters makes his influence

${ }_{3}$ McArthur v. Moffett, $\mathrm{I}_{43}$ Wis. 564, 567, r28 N.W. 445, 446, 33 L. R. A. (N.S.) 264, 266 (rgrr).

14 See discussion in Clark, The Union of Law and Equity, 25 Col. L. Rev. I (I925); Clark, Code Pleading (r928), 47 el seq. particularly cases cited in note 36 on p. 50, also p. 70 , and p. I82, note 156 ; also cases in Clark, $x$ Cases on Pleading and Procedure (r930), 505-59r, notably cases cited on 526 . See also Walsh, Equity (1930), 96-r 3 ; Walsh, Merger of Law and Equity under Codes and Other Statutes, 6 N.Y.U. Law Rev. 57 (r929); Cook, Equitable Defenses, 32 Yale L. Jour. 645 (I923); Clark, Trial of Actions under the Code, I I Corn. L. Q. 482 (r926); Rothschild, 27 Col. L. Rev. 258, 262-265 (r927); 37 Yale L. Jour. 654, 66I-666 (rg28). The contrast may be shown by Poth v. Washington Sq. M. E. Church, 207 App. Div. 219, 20r N.Y.S. 776 (1923) from the first department, with Port v. Holzinger, 212 App. Div. I24, 208 N.Y.S. 287 (I925) from the second department. 
most potent for efficient court administration. ${ }^{15}$ Meanwhile in many, and apparently most, of the code states, including those as widely separated as Connecticut and Cahifornia, a simple and effective system has been worked out where the pleading stage of trial is not controlled by the ancient separation of law and equity. ${ }^{16}$ Often where the amount of hitigation warrants it a mere division of trial calendars into jury cases and court or jury-waived cases is a business-ike means of classification preparatory to assignment for trial; but no other or different distinction is necessary or should be made.

Any attempt to preserve the ancient distinctions is therefore an effcient trouble-maker rendering the procedure uncertain, and, where really enforced, leading to anomalous results in the dismissal of cases, disgraceful to any system which purports to administer justice. ${ }^{17}$ It may be hoped, therefore, that the Illinois judges will seize on the opportunity afforded by the joinder provisions, referred to above, to avoid such a result.

The hesitation shown by the legislators in approaching this vital problen goes back to the Original Draft of the Bar Association, where these provisions, though somewhat different in wording and arrangenient, contained substantially the final himitations. ${ }^{18}$ Another guarded change of similar import was, however, subjected to restrictions only while the drafts were under consideration. The Original Draft in Section 24 contained the provision, taken from code practice, that actions "may be brought in the

xs Compare his leadership in extension of the summary judgment, Finch, op. cit., supra, note 8.

${ }^{16}$ See articles cited in note 14 , supra. Among many authorities the following are examples, White v. Lyons, 42 Cal. 279 (r87r); Thiel v. Miller, r22 Wash. 52, 209 Pac. rc8r, 26 A.L.R. 523 (r922); Rath v. Wilgus, rro Neb. 8ro, r95 N. W. Ir 5 (r923); Bisnovich v. British America Assur. Co., roo Conn. 240, 248-250, I23 Atl. 339, 34x-2 (r924); Gest v. Gest, I67 Atl. go9 (Conn. r933) (saying that where a jury is present the better practice is to submit all issues to it, the court upon their findings to grant the proper relief). Where, however, the parties are definitely at odds as to whether a trial by jury may be had as of right, the court must decide the question looking to the nature of the issues and the historical mode of trial. Rey v. Moore, 85 Conn. ${ }_{59}, 82$ Atl. 233 (rgr2).

${ }^{17}$ See the New York cases referred to in note 14 , supra, and compare Glaser v. Columbia Laboratories, Inc., r67 Atl. 20r (N.J. r933) (partial assignment "unenforceable at law"); San Giacomo v. Oration Inv. Co., 143 Atl. 329 (N.J. I928) ("legal" question as to whether complainant might collect interest on an overdue mortgage debt not within the jurisdiction of chancery).

${ }^{8} 8$ Section 33 of the Original Draft provided: "No distinctions of form need be observed between the different ordinary actions at law, and there shall be no further distinctions of form between actions at law and suits in equity than those indicated in this act and the rules adopted pursuant thereto." A final paragraph of the same section contained the substance of what is now Section 44 (2) providing for the transfer of actions between "law docket" and "equity docket." In fact the wording of the Act here is more general than that of the Draft. The latter 
name of the real party in interest," and, to avoid all question, there was added "or in the name of the holder of the legal title to the right asserted or in the names of both." This exphicit statement avoided the difficulty experienced in some of the early code cases, where the courts, misled by the word "real," held that only a beneficial owner might sue and thus refused recovery to an assignee for collection only. The true construction, however, that no change in fundamental rights was intended by the code reform and that anyone having a recognized jural right night sue ${ }^{x 9}$ has long been generally established and was affirmed in this provision. But it was omitted by the Bill before the legislature, which contained only the former law that the assignee and owner of a non-negotiable chose in action may sue in his own name, and this was later amended to include the former statutory requirement in full so $^{20}$ that such a plaintiff "shall in his pleading on oath, allege that he is the actual bona fide owner thereof, and set forth how and when he acquired title." ${ }^{2 x}$ Thus is reenacted the harsh Illinois rule that an assignee for collection only cannot sue. ${ }^{22}$ There seems no reason why the simple and convenient business practice of transferring claims merely for the purpose of collection should be objected to, or why the courts should be placed in the position of aiding a defendant in making a highly technical defense. The Original Draft was much to be preferred. ${ }^{23}$

An advantage clained for the new Practice Act is that it does away with "blind pleadings." 24 This apparently is to be achieved under various sections requiring the pleadings to be specific, notably, Section 40 , which also does away with the general issue. Carrying out this plan Section 35 ,

authorizes the transfer of "any action or counterclaim in equity" on the "law docket" and of "any action or counterclaim at law" on the "chancery docket," while the former permits the transfer of "any cause of action or counterclaim." The Bill and the Act are identical. For a protest made by a member of the bar against even a limited change, see Illinois State Bar Ass'n Rep. I932, 32r. But protests from the bar as to changes in established practice must unfortunately always be expected. Compare Sunderland, The Enghish Struggle for Procedural Reform, 39 Harv. L. Rev. 725 (r926); Clark, Code Pleading (I928), 27, 35.

${ }^{x}$ See Manley v. Park, 68 Kan. 400,75 Pac. 557,66 L. R. A. 967, I Ann. Cas. 832 (rgo2) overruling Stewart v. Price, 64 Kan. I9x, 67 Pac. 553, 64 L. R. A. $58 \mathrm{r}$ (Igo2). But see Brown v. Ginn, 66 Ohio St. 3r6, 64 N. E. r23 (rgo2). Cf. Clark, Code Pleading (r928), 96, roo.

${ }^{20}$ Ill. Rev. St. I93I, c. rro, § I9.

25 Civil Practice Act, $\$ 22$.

${ }^{22}$ Gallagher v. Schmidt, $3^{\text {I } 3}$ Ill. 40, I44 N. E. $3^{\text {Ig }}$ (rg24) reversing 23r Ill. App. r68 (I923).

${ }^{23}$ Like provisions in the same section control action for the subrogee, the action to be brought "either in the name of, or for the use of the subrogee," an expression reminiscent of common law pleading.

${ }^{24}$ Jeuner and Schaefer, op. cit., supra, note 3. Compare Sunderland, The Civil Practice Act of 1933 (introduction to the Act in Calilll's Revised Statutes, 1933). 
like the original New York Code, provides that a party by verifying his own pleadings may force all later pleading to be supported by oath. One may perhaps doubt whether the purpose in mind has been achieved in the Act and further how desirable it in fact is. It may be recalled that the first fruit of the agitation for pleading reform in England was the adoption of the Hilary Rules of 1834 . The man primarily charged with the drafting of these rules was quite naturally that pleading master, Stephen, whose crime it was that he made common law pleading seem simple and attractive. His view of reform was to have more, much more, and stricter pleading. Hence the Hilary Rules himited very greatly the effect of the general issue and called for precise and specific allegations and denials. At no time in the history of our law has pleading been as technical or as difficult or destructive of the rights of innocent litigants as in the decade or two after these rules were adopted and before changes going in the opposite direction were made. Professor Holdsworth in a notable article has pointed out some of the results upon our law in bringing ahve old technicahties and in turning the current of even substantive law into ancient and arbitrary channels. ${ }^{25}$ We are not hikely to repeat that experience for the reason that we, unlike Baron Parke and his colleagues, lack the courage of our convictions so that we will not penalize a pleader by the only effective sanction there is for such rules, namely, loss of the case. Such a harsh penalty for ignorance, carelessness or, perhaps more often, justifiable uncertainty is properly abhorrent to our sense of justice. At most we may occasionally-very occasionally - attempt to apply the ineffective punishment of taxing extra costs ${ }^{26}$ but generally we shall only spend time and energy in a profitless endeavor to perfect the written record, or to exhort the parties to do so, while they successively, though not concurrently, resist our efforts.

The fact of the matter is that such an attitude represents an attempt to assign to the formal pleadings a role they are actually not fitted to fill. It is true that the code ideal was to "plead the facts," but in experience this was the least successful part of the code reform. ${ }^{27}$ The parties will not

${ }_{25}$ Holdsworth, The New Rules of Pleading of the Hilary Term, I Camb. L. Jour. 26r (rg23). Cf. Reppy, The Hilary Rules and Their Effect on Negative and Affirmative Pleas under Modern Codes and Practice Acts, 6 N.Y.U. L. Rev. 95 (r929).

${ }^{26}$ The Illinois provision, C. P. A. $\S 4$ I, seems singularly weak; "such reasonable expenses . . . a may have been actually incurred by the other party, by reason of such untrue pleading." The difficulty and usual impossibility of enforcing a penalty under such a rule may be perceived.

${ }^{27}$ Cf. Cook, Statements of Fact in Pleading under the Codes, 2I Col. L. Rev. 4r6 (I92I); Clark, The Complaint in Code Pleading, 35 Yale I. Jour. 259 (I926). 
reveal their entire stories until the time comes when such revelation is necessary and worthwhile. That in the usual case is at the actual trial or, when the modern procedural short cuts of summary judgment, examination, and discovery are used, it is at the affidavit or examination stage of the proceedings. ${ }^{28}$ At these times the whole case will be brought out because here failure of a party to disclose is followed by loss of the case. The pleadings in reality are only the more or less standardized and formal statements which define broadly the ultimate boundaries of the litigation. They are important and helpful in so doing, for they permit of early sorting and classification of types of cases preparatory to disposing of them quickly and efficiently. Here in fact is probably the greatest opportunity for advance in effective law administration-increased use of sortimg techniques looking to more effective case disposition. The summary judgment and the other new devices are first steps which should be followed by careful study and test of others. The pleadings in addition provide the formal basis for the ultimate judgment and thus define the himits of its Iater application both on appeal and as res judicata. They are important, but they are not the evidence or the proof of the case and efforts to make them a substitute therefor seem doomed to futility. Generally in this country, therefore, the attempts to do away with the use of the common counts in the complaint, or to dispense with the general denial or to make the verification of pleadings of any real significance in the case have not succeeded.

Hence while admonition to pleaders to set forth their facts precisely may be not out of place in a code as counsels of ideals to be followed and as aids to making the pleadings more effective for their actual purposes, yet time-tried and effective short cuts such as the common counts and the general demial should not be frowned upon. Nor should the courts be commanded to waste much effort in polishing up the formal allegations. Rather should they be encouraged to devote their attention to the application of the modern substitutes for the time-consuming trial, and to extend the usefulness of the sumniary judgment and other like devices.

The explicit direction in the Act that certain named defenses, such as payment, release, fraud, and the hke, must be affirmatively pleaded sensibly carries out this view and removes the manner of raising these issues from the uncertainty which often surrounds them in code practice. ${ }^{29}$

${ }^{28}$ See supra, note 8.

${ }^{29}$ C. $\dot{P}$. A. $\$ 43$. The catch-all phases at the end, referring to defenses "which by other affirmative matter seeks to avoid the legal effect of or defeat" the plaintiff's case (a perfect circle-affirmative defenses must be pleaded as affirmative defenses) and defenses "likely to take the opposite party by surprise" are not illuminating; though perhaps some generality is called for here to give the court scope to apply the rule to analogous cases. 
Other desirable pleading changes incorporated in the Act cannot be discussed in detail. They include clear provisions as to the office and effect of the prayer for relief $;^{30}$ authority for pleading in the alternative $;^{3 \mathrm{x}}$ for pleading together defenses to the jurisdiction, in abatement and in bar; ${ }^{32}$ and for entering split judgments for or against various of the parties; ${ }^{33}$ and, with respect to amendments, the continuance and extension of the Act of 1929 , which did away with an unusually illiberal earher rule restricting their grant. ${ }^{34}$ The provision abolishing demurrers is in line with modern reform, but it is doubtful if the purpose is achieved by merely substituting a motion therefor. The English practice of the "objection in law," which is heard before the trial only when the court concludes that a decision upon it will substantially dispose of the whole action, ${ }^{35}$ is preferable since it does away with the dilatory results of an extra stage of argument and ruling, not determinative of the case. The motion unfortunately does not avoid this chief objection to the demurrer.

On matters of appellate review, the Act is limited to improving the mechanics of review and does not introduce any innovations beyond the usual rules of most states. In fact the improvements here adopted should have been made before as they correct technicalities which were needlessly encumbering Illinois appellate procedure.

With respect to the jurisdiction or scope of appellate review no cliange is made. As to cases which go from the appellate court to the Supreme Court, the former by issuing a certificate of importance may still certify questions to the highest court, while that court may order the intermediate appellate tribunal to send a cause to it for review by "leave to appeal," equivalent, except for the name, to the former certiorari. ${ }^{36}$

The primary clange in method is to substitute a broader appeal for the

$3^{\circ} \S 34$, providing that the prayer for relief does not limit the relief, except in cases of default, thereby avoiding a pitfall of many codes which limit the rehief ambiguously to the case where the defendant has not answered. Clark, Code Pleading (1928), I79-I87. The Illinois section also makes provision designed to protect a party agaïnst prejudice by reason of surprise on clains for other relief.

${ }_{3 x} \$ \$ 34$ and 43 (2); also $\$ \S 23,24$ as to joining parties in the alternative.

$32 \$ 43(3)$.

$33 \S 50$. This is usual under code practice, but this statute contains special provisions avoiding the discharge of a joint contractor by a judgenent against his co-contractor.

${ }^{34}$ Laws 1929, p. 578, Rev. St. 1931, c. Iro, $\$ 39$. For the previous rule whicl was based on a narrow construction of cause of action and which effectively prevented even slight amendments after the statute of limitations had run, see N. \& G. Taylor Co. v. Anderson, 275 U.S. 431, 48 Sup. Ct. 144, 72 L. Ed. 354 (1928); 36 Yale L. Jour. 852 (1927); 22 Ill. L. Rev. 309 (1927); 4 Ill. L. Rev. 344 (1909).

35 English Rules under Judicature Act, Order 25, Rules I-4.

.${ }^{36}$ Illinois C. P. A. $\$ \S 75,77,78: \S$ Iro (rule I6). 
former methods of review, notably the appeal and the writ of error. ${ }^{37}$ It has been unfortunate that these two methods, largely overlapping but the exact limits of which have not been wholly clear ${ }^{38}$ should have existed to the confusion of bench and bar, and the attempted simplification is most desirable. Unfortunately since certain specific actions are not changed by the Act, there may still be cases where the older forms of review must be employed, and there is even a possible constitutional question whether writ of error can be abohshed or its identity changed or lost. ${ }^{39}$ It is to be hoped, however, that these difficulties can be met in such way as not to limit the real reform intended.

Another important step has been taken in connection with the record on appeal. Formerly the preparation of the record was a serious and difficult if not disastrous matter for appellants. A sharp distinction was recognized between the record proper (the old common law record) and the transcript of proceedings in the trial itself, usually called a "certificate of evidence" in equity and a "bill of exceptions" in common law proceedings. It was often not clear when a paper should be in the record and when in the transcript, but if counsel made a mistake, the document was not regarded as before the court even though it appeared in some other place in the appeal record..$^{\circ}$ All distinctions between parts of the record are now abolished and all documents before the court on appeal may hereafter be considered by the court for all purposes..$^{4 x}$

Important practical changes have been made with reference to findings of fact. Heretofore the statute has required the Appellate Court, where it finds any facts different from those found by the trial court, to make a formal recital in its final order of the facts found. Now it is also stated that this court's final order shall not be reversed by the Supreme Court

\section{Tllinois C. P. A. \& 74 et seq.}

${ }^{38}$ The distinctions which have existed between the appeal and the writ of error are summarized in Dodd and Edmunds, Illinois Appellate Procedure (r929), $\S$ I80. The appeal was in many ways a simpler and more flexible proceeding which must be promptly taken and bond given; while the writ was a new action brought by parties perhaps not of record and without giving bond, any time within two years. The new plan is an attempt to unite the advantages of each with a much shorter period than the old writ-ninety days-but subject to some extension by the court for cause. C. P. A. $\$ 76$. The time allowed for appeal still seems substantial, if not excessive.

39 I am indebted to my former colleague, Mr. Walter F. Dodd, of the Chicago bar, for many suggestions as to the effect of the new Act on appellate procedure. He is, of course, not responsible for the use I have made of them nor for my conclusions.

$4^{\circ}$ Frank v. Chicago, 216 IIl. 587,75 N. E. 2×3 (rgo5); Jenner and Schaefer, op. cit., supra, note 3,67 .

4I IIl. C. P. A. $\S 74$ (2). 
for failure to recite such facts if they sufficiently appear in the opinion or in the order or from an examination of the two. ${ }^{42}$ Thus is avoided a reversal for this technical mistake not affecting substantive rights. It is further provided that in cases tried without a jury no special findings of fact by the trial court are necessary to support the judgment or decree. ${ }^{43}$ This is particularly valuable as changing the rule previously applied in chancery cases that the decree must recite every fact necessary to support it, a rule placing the burden of supporting the decree upon the court making it, and hence upon the successful party, whereas the burden of making the record on review ought to be on the person launching the attack.

In general, however, no change has been made in the power of the appellate tribunals to review facts. This means, as heretofore, that the Appellate Courts have broad powers to review facts, himited somewhat in jury cases, and that the Suprene Court has like powers in all chancery cases and in cases coming to it directly but not in cases coming from the Appellate Courts. ${ }^{44}$ The matter of the extent of the review of facts is a troublesome one in appellate procedure generally, but in view of the general scope of the new Act it is not surprising that no change was attempted. Moreover, the attitude expressed in the Act agamst a complete amalgamation of law and equity indicated that the old chancery review would be preserved. This is unfortunate. There seems no reason, except the historical one which should no longer be determinative, why review of jury-waived cases and review of chancery cases should differ. Not only is the resulting confusion unnecessary, but such a distinction has unfortunate results beyond the appellate courts in tending to induce the trial courts to enforce the division even back at the stage of pleading and before it is clear that there will be a trial, much less an appeal. The rule adopted in many, though not all, the code states, of a chancery review himited just as is a legal review, seems preferable. ${ }^{45}$

Whether American courts should go further and attempt to dispense with the distinction between fact and law is a real problem. The distinction is a most unmanageable one, since there is no clear cut hine between

${ }^{42}$ C. P. A. $\$ 89$, extending Rev. St. I93I, c. I ro, \$ I I9.

${ }_{43}$ C. P. A. $\$ 64$, subdivisions (2) and (3).

${ }_{44}$ C. P. A. $\$ 9^{2}$ (b); Dodd and Edmunds, Illinois Appellate Procedure (r929), c. 29, and especially $\$$ III4.

${ }^{45}$ See New Mexico, Code I91 $5, \$ \S 4$ r97, 4507; Fraser v. State Sav. Bank, I8 N. M. 340, I 37 Pac. 592 (rgr3); Meriden Trust and Safe Deposit Co. v. Miller, 88 Conn. 157, go Atl, 228 (Igr 5); Berry v. Merrill, x6I Atl. 34 (N.H. 1932). But see Carroll v. Bullock, 207 N.Y. 567, ror N. E. 438 (rgr3); Campbell v. Gowans, 35 Utah 268, roo Pac. 397,23 L. R. A. (N. S.) 4r 4, rg Ann. Cas. 660 (rgog). 
the two concepts; and appellate practice is confused and uncertain because the reviewing court seems often to take jurisdiction or not, as it chooses, and only rationalizes the result by applying the label of law or fact as it needs. ${ }^{46}$ On the other hand, even without constitutional hmitations on review of facts, all courts of review properly wish to avoid the regular examination of testimony taken below. The trier of facts who has observed the witnesses can decide such questions better than the appellate tribunal, and the sheer drudgery facing the latter courts to no good purpose is persuasive agreement for some limitation. But a more realistic formulation of the test should be made, unless, indeed, we are prepared to adopt the English system where the appeal is a rehearing and not a search for error. Much is to be said for this plan which, in the first instance, at least as applied to the English Court of Appeals, ${ }^{47}$ calls for an examination of the entire case below with additional testimony if necessary with the objective of entering. whatever judgment the case requires. ${ }^{48}$ Along with this should go, however, the simple Enghish system of not having the formal and formidable printed record, but of furnishing the appellate court with special copies of all documents togetler with the trial judge's notes of the evidence (and more rarely a transcript of the evidence). ${ }_{4} 9$ Such simplicity is most desirable; it may be prevented by appeal fees from fostering improper appeals. It seems, however, not yet at least in line with American conceptions of review.

Two provisions of the new Act do, however, look somewhat in the direction of the English position and may well be watched with much interest. One is the authority to the reviewing court to "give any judgment and make any order which ought to have been given or made."50 The other is the power to grant amendments and receive further testimony in

${ }_{4}^{6}$ The Illinois experience in applying the distinction is apparently similar to that in other jurisdictions. Dodd and Edmunds, Illinois Appellate Procedure (1929), \$§ IrII-Irr3. Cf. Sun-

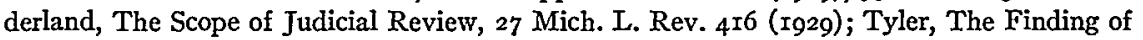
Facts in Connecticut, 4 Conn. Bar Jour. 265 (r93o) and suggestion to the Connecticut Judicial Council of a modified form adopted from the Enghsh system. Second Report, Conn. Jud. Council (r930), 94-Ior. For discussions of the meaming of fact and law, see articles by Cook and Clark cited supra, note 27 .

${ }^{47}$ The ultimate appeal to the House of Lords is made cumbersome, expensive, and difficult. See next note.

${ }_{4^{8}}$ Clark, English Appellate Procedure, 39 Yale L. Jour. 76, 86 (r929). Cf. Sunderland, op. cit., supra, note 46 .

49 Ibid. See also Sunderland, The Problem of Appellate Review, 5 Tex. L. Rev. I26, r39-148 (r927); 3 Umiv. Cin. L. Rev. I, 14-23 (r929).

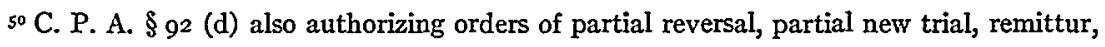
etc. 
the reviewing court. ${ }^{5 x}$ This power has been granted in a few American jurisdictions and, while usually sparingly exercised as yet, may be the means of avoiding an unfortunate and unnecessary further trial of a case..$^{52}$

In the outstanding authority on Illinois appellate procedure, the authoritative volume by Messrs. Dodd and Edmunds, is a fine plea for a complete study of appellate review in that state with a view to extensive reform. ${ }^{53}$ It is obvious that the plan of the draftsmen of the Act has been more modest, and that more extensive reform must be postponed, while the technical defects are being corrected by the Act. Moreover, though the general problem is troubling many American states and some have tried revamping of their systems, yet study and solution are still mainly in the future..$^{54}$ We may hope for much more expert advice on these matters, in the future, but pending this the more limited objective of the Illinois Act is understandable and justifiable.

In general summary one may say that the new Act, because of its specific reforms and because of the possibilities for flexible construction and enliglitened application which it affords, deserves the support of Illinois bench and bar. It corrects many specific defects and blemishes of Illinois practice, and in some of its provisions, notably those on joinder of actions, it offers means of achieving an unusually advanced system of civil procedure.

sI C. P. A. $\$ 92(a)$-(d). The testimony may be received "where evidence has been erroneously excluded or where there has been an omission of proof at the trial of some facts, which, under the circumstances of the case, may subsequently be proved without involving any question for a jury and without substantial injustice to either party.

${ }_{52}$ Scott, Fundamentals in Procedure (1922) I60, I61, 167; Albertsworth, Procedural Reform, 7 Corn. I. Quar. 327 (1922); Clark, Code Pleading (I928), 36, 5 I $2 ; 38$ Yale I. Jour. 398 (I929); $3^{2}$ ibid. 506 (x923). For statutes as to taking testimony on appeal see Cal. Stats. of I927, 583, C. C. P. $\$ 956$ a; Kan. Rev. Stat. (I923), 60-3316; Mass. Gen. Laws (I921), c. 23I, § I25; R. I. Gen. Laws (r923), c. 339, § 30; I6 Cal. L. Rev. 500 (I928); 3 So. Cal. L. Rev. 35 I (1930); Hummel v. Muller, I02 Cal. App. 474,283 Pac. 87 (x929); Bankers Mtg. Co. v. Dole I 30 Kan. 647,287 Pac. 906 (I930); Haynes v. Greene, 46 R. I. 32, I34 Atl. 853 (I926); 36 Yale L. Jour. 570 (I926).

53 Dodd and Edmunds, Tllinois Appellate Procedure (I929), c. 37, especially $\S \times 435$.

54 Compare the various suggestions and the limited change finally adopted in Connecticut. Second Report of Conn. Judicial Council (I930) note 46, supra; Beers, Appeals and The New Rules, 6 Conn. Bar Jour. 12 (1932). See also other citations in notes 46, 48, and 49, supra; Third Report of Michigan Judicial Council 1933, Appendix: Study of the Organization and Operation of Courts of Review by Curran and Sunderland, 51-246; Dodd, The Problem of Appellate Courts, $6 \mathrm{Am}$. X. Sch. Rev. 68I (I930); Sunderland, Intermediate Appellate Courts, 6 ibid. 613 (1930). 